\title{
Emerging Economies - Fiscal Policies and International Relations
}

\author{
Alicja Brodzka \\ Wroclaw University of Economics, Wrocław, Poland
}

\begin{abstract}
Recent political, economic and social changes in the developing parts of the world have caused the growth of their position in the international arena. Last years have also shown that there is a potential for stimulating the emerging economies through tax reforms and developing fiscal issues. Developing countries, in their attempts of increasing tax revenues, face various constraints - both at the domestic and international level. The article focuses on main aspects of fiscal policies of less developed territories and presents problems and challenges of the taxation area. The paper also examines two instruments, often used by developing countries in order to attract the foreign capital and stimulate their economies: tax incentives and double tax treaties. The last part of the article analyses the new role of BRICS - the most dynamically developing economies - in the world of international relations.
\end{abstract}

Keywords: developing countries, BRICS, tax systems, tax incentives, international fiscal issues.

\section{Introduction}

Last year witnessed a substantial reduction of poverty in emerging economies, both BRICS (e.g. Brazil, Russia, India, China and South Africa) and smaller developing countries. In the period between 1981 and 2005 China dropped from $84 \%$ to $16 \%$ in the percentage of their population living below the poverty line, India from $60 \%$ to $42 \%$, and Brazil from $17 \%$ to $8 \%$ respectively (Ravallion, 2011). At the same time the nature of poverty has changed as poor groups are present within more countries, also including the OECD ones. The other phenomenon in modern world is huge increase of inequalities in income and wealth. According to OECD, most of last years' growth went to the top $1 \%$ of the population and over 2010 the gap between rich and poor countries has doubled. The increase of inequalities is present not only in developing territories, but also in the developed ones - the 2011 estimates show that the top $1 \%$ of US earners now commands $40 \%$ of country's wealth; the top $20 \%$ of them own almost $85 \%$ of total wealth. The fact that for last 20 years most of the 30 developed OECD countries have experienced thie same drift towards higher inequality proves that it is a problem happening across the globe; nevertheless the stratification in wealth and income in poorer economies is much more severe and visible (Australian School of Business, 2012).

There are also some positive aspects of last years' changes in developing world - a growing role of BRICS economies, dynamic development in South and Latin America, much more optimism about the future in Africa. Especially Africa is experiencing greater stability, much sound economic policies, less poverty. It seems that there is a big potential in developing countries for stimulating their economies through

Copyright (C) 2012 Alicja Brodzka. This is an open access article distributed under the Creative Commons Attribution License unported 3.0, which permits unrestricted use, distribution, and reproduction in any medium, provided that original work is properly cited. Contact author: Alicja Brodzka E-mail: alicja.brodzka@gmail.com 
fostering the state-building. It is also a room for tax reforms and developing fiscal issues, which for a long time have been an obstacle in creating modern investment environment in less developed territories (Owens, 2012).

The aim of the research is the analysis of the main aspects of developing countries' fiscal policies. The article focuses on problems and challenges of taxation, faced by less developed territories in the process of implementing modern tax solutions. Developing countries in their attempts of increasing tax revenues suffer various constraints - both at domestic and international level. Next the author presents the problem of tax incentives offered by developing countries in order to attract the foreign capital. She asks the question whether the effectiveness of tax incentives is not an illusion and whether they are really good solution for described territories. She also points at the controversial role of double/multinational tax treaties in the process of stimulating the developing economies. The last part of the article analyses the new role of BRICS - the most dynamically developing economies - in the world of international relations.

\section{Taxation Issues in Developing Economies}

In the common meaning developing countries are those territories, which have not achieved a significant degree of industrialisation relative to their population, and which offer lower standard of living for their citizens. The shortest definition of developing states includes all countries that are in the way from developing to a developed economy. Some several countries with transition economies are sometimes grouped with developing countries based on their low or middle levels of per capita income, and sometimes with developed countries based on their high industrialisation. The most popular assumption states that over $80 \%$ of the world's population lives in more than 100 developing territories. Nowadays economists treat as developing countries the poorest territories, recipient of financial aid, having development and funding of basic needs as the main priority. Most of them are located in Africa, Asia and Pacific (Nielsen, 2011). They are generally characterised by subsistence agriculture and varying degrees of lack of competitive industries and exploitable natural resources. Many of them suffer from natural disasters, dependency on external aid and no ability of significant improvement in economic prospects in the foreseeable future. The author, in the next section of the article, will focus on such territories, by analysing the most crucial issues of their taxation systems.

Taxation as an important element of economic policy, if wisely projected and implemented, can be effectively used by governments of developing territories. Fiscal policy can become a tool not only to provide predictable state revenues, but also to encourage the state-building and to create tax-responsible society. More advanced fiscal aspects, like enhancing transparency, fighting corruption and tax evasion, strengthening the fiscal cooperation and developing tax agreements with third countries can also improve the state's position in the international arena. As such, the development goals and the goals of taxes start to be complementary in the process of strengthening economies.

In the case of developing countries the main problem is the sustainable provision of public services necessary to strengthen the economic development. The tax-to-GDP ratio in developing countries ranges between 10 to $20 \%$ as opposed to 25 to $40 \%$ in developed ones. Increasing domestic revenue would not only create additional space for supporting the economic growth, but would also allow the State to assume ownership for its policy choices (Cooperating with Developing Countries..., 2010). There is also a crucial issue of capital flights and illicit financial flows, which are explicitly identified as a major obstacle to mobilisation of domestic revenue for development. According to a Norwegian government commission (2009) 
illegal money flows from developing countries totalled 641 to 979 billion USD in 2006, which gives a number at least seven times higher than official development assistance.

Developing countries, in their attempts to increase their domestic tax revenues, face several constraints, linked both to international and domestic factors (Cotarelli, 2011). At the domestic level emerging economies are confronted with three groups of problems:

- The structure and competitiveness of the economy (with constraints manifested in large informal sectors, predominance of agriculture over industry and services);

- Political and macro-economic instability, poor governance and deficient rule of law (including in resource-rich settings and particularly severe in countries in situations of fragility), poor public service delivery, low quality of public finance management, and the problem of corruption;

- Weaknesses of the tax system and its management that may explain the limited effectiveness and responsiveness of tax reforms, with problems such as: (1) the narrow tax base often leading to an uneven distribution of tax burden between economic factors and taxpayers; (2) the balance between direct/indirect taxation that not always appropriately reflects the structure of the economy; (3) weak links between tax policy and tax administration; (4) lack of capacity of tax administrations to operate and supervise the tax system, which can result in low tax compliance and collection.

At the international level developing countries have to deal with the increasing integration of international markets and the economic globalisation. That also affects the effectiveness of their tax systems, as implementation of domestic tax rules becomes difficult in a world with an increasing geographical mobility of taxpayers and capital flows (especially combined with the use of new technologies). The transition from national tax systems largely dependent on customs revenue to broader and more modern ones creates serious adjustment issues. Developing countries in their attempts might be tempted to encourage the foreign financial flows through too costly tax incentives and derogations which often fail to attract real and sustainable investment. And - last but not least - the existence of noncooperative jurisdictions and harmful tax practices, both in developed and developing countries, is detrimental also to developing countries by not only having a negative impact on their revenues but also by undermining good governance and institutional development.

Improving taxation goes beyond reaching the competitive tax rates. It requires governments to strike a balance between providing solid taxation to governance structures and improving domestic resource mobilisation. A growing number of developing countries consider fundamental reforms to increase their revenue and to address inefficiencies of the current system. Tax reforms need to be promoted to widen the tax base and bring a larger part of the population into the formal economy (Political Economy of ..., 2007).

\section{Tax Incentives and Double Tax Treaties - The Case of Developing Countries}

Tax incentives are special elements of the tax code designed to compete for corporate site selection projects and to encourage a certain types of behaviour. Developing countries introduce incentives in order to attract capital and support the economic growth. Incentives are often treated as a counterweight to the investment disincentives inherent in the general tax system. They can also be treated as an offset to disadvantages that investors may face, such as a lack of infrastructure, complicated and antiquated laws, bureaucracy and weak administration, both in the tax area and 
elsewhere. In theory the inflow of foreign capital, attracted by tax incentives, can support reforms of the existing, problematic laws and help building the necessary administrative capacities.

Tax incentives can be grouped into four categories: (1) tax holidays; (2) investment allowances and tax credits; (3) timing differences; (4) reduced tax rates. With a tax holidays, new companies are exempted from the burden of income taxation for a period of time. Sometimes, this grace period can be extended to a subsequent period of taxation at a reduced rate.

Investment allowances and tax credits are forms of tax relief, based on the value of expenditures on qualifying investments. They provide tax benefits over and above the standard depreciation allowed for the asset. The tax allowance is used to reduce the taxable income of the company, whereas the tax credit results direct reduction of the amount of taxes to be paid.

Timing differences can arise in two ways: through the acceleration of deductions or the deferral of the recognition of income. The most common form of accelerated deduction is accelerated depreciation, where the cost of an asset may be written off at a rate that is faster than the standard economic rate of depreciation. It can take the form of either a shorter period of depreciation or a special deduction in the first year. Important timing differences can occur also in more technical areas, when income may not be realised until there is a sale of an asset, whereas certain costs are recognised immediately.

General tax rates' reductions can be provided for income from certain sources (or to business entities) satisfying certain criteria. It can be a criterion of size (small enterprises etc.), sector (agriculture etc.) or the origin of money (foreign direct investment etc.). Tax reductions differ from tax holidays as the companies' tax liability is not entirely eliminated, only the benefit is extended beyond new enterprises to include income from existing operations, and the benefit is not time limited (Holland, Vann, 1998).

According to Y. Brauner (2012) tax incentives, as pervasive, universal and standardised, create a predictable set of encouragements for multinational enterprises (MNEs) searching the optimal location for their investment and often using tax optimisation practices. In analysing the issue of this kind of fiscal instruments one usually takes the natural order of deduction: tax incentives enhance foreign direct investments and as such have a positive influence on economic growth, which strengthens the development. This way of thinking is currently criticised by international economic organisations, which perceive tax incentives both inefficient (as they intervene with the market), and ineffective (as multinational enterprises in reality do not care about such incentives). The international institutions quote that tax incentives are probably harmful for the development as they often cause so called "race to the bottom". In this context tax incentives would not be the case of stimulating the development but rather developing the tax competition.

The next difficult issue is the lack of the information about the real costs and benefits of implementing tax incentives into the tax systems due to problems with data availability. In countries with weak political systems and powers it is difficult to check if (and how) tax incentives work. No cost/benefits initiatives cause that the developing countries do not really control their tax incentives policies. In fact it seems they are being drawn to use them by the developed part of the world - to develop themselves they have to create incentives in order not to be uncompetitive towards other territories.

Important problem connected with such measures is the fact that for real developing countries tax incentives are very heavy burden, additionally strengthened by the exploitive competition between 
neighbouring countries. Attracting foreign capital does not automatically mean bringing the newest technology and ensuring the economic growth. MNEs with their FDIs indeed invest money and bring some technology into developing countries, but very often as the next step they choose squeezing the market, elimination of local entrepreneurs and tightening the local competition. As a consequence the importance of tax incentives proposed to MNEs seems to be overestimated.

The developing countries in adjusting their tax policy have to be conscious that the changing policy has to reflect their true priorities. There is a necessity to put more emphasis on developing tax administration, restructuring its structures and training and better paying people hired in tax structures. Also working on the set of incentives in order to attract foreign capital is a complex issue facing a lot of challenges. There is a strong need for developing countries to bear in mind the necessary conditions when giving the tax incentives: (1) making sure that the incentive is transparent and the cost of its implementation is known; (2) identifying tax payers who benefit from the incentive; (3) analysing how effective the benefit is; (4) making sure it is not harmful for the system. The above mentioned issues seem to be the biggest challenge is situation of week administration, corruption and poor, undertrained and underpaid tax personnel. All those constraints have to be overcome, as at present as they now constitute large ballast to emerging economies (Owens, 2012).

In the area of international taxation and international relations there is also an important issue of tax treaties. Double tax treaties (DTTs) are designed to mitigate the effects of double taxation, which can arise in transnational business relations, by creating a fair share of tax base between two treaty partners. The DTTs' aim is promoting communication between countries, helping to counteract tax avoidance and evasion, encouraging the elimination of tax measures which distort international trade and investment flows and promoting mutual assistance between countries. Tax treaties may cover various types of taxes, mainly the direct ones (income taxes, inheritance taxes or others), but also the indirect fiscal burdens (VAT). Double tax treaties help developing economies in attracting foreign capital, as they prove the governments' will to create competitive and stable environment for foreign investments.

In the process of treaty negotiations countries often use as their base model tax treaties, prepared by international institutions. The main tool which aims at supporting the tax policies of developing countries, is the UN Model of Double Taxation Convention between Developed and Developing Countries (1980, revised 2001). Among the Convention's general objectives there are: protection of taxpayers against double taxation, prevention of the potential discouragement for free flow of international investment, prevention of discrimination between taxpayers in the international field, and provision of legal and fiscal certainty as a framework for carrying international operations (Brodzka, Garufi, 2012).

This is something what theory says. According to Y. Brauner the reality is quite different. Solutions included in the UN Model Tax Treaty are not very often used in treaties with developing countries, as usually it is a second partner - not the developing state which has the stronger voice in treaty negotiations.

And there is also transnational capital, which plays a significant role. Multinational enterprises often stimulate the process of signing double tax treaties in countries they want to invest; in fact they are the real persons taking advantage from tax agreements. It seems that thinking that the treaties are designed to create the fair share of tax base and stimulate the development of weaker and poorer economies is no more but "illusion" in the world of big transnational companies. Multinational enterprises, in the 
process of choosing the location, ask each of neighbouring developing countries for proposals of incentives. By using its dominant position MNEs force the developing countries to proposed solution harmful for their systems, causing real "race to the bottom".

\section{New Big Players on International Arena}

Most developing countries are economies in transition or the poorest economies, being recipients of financial aid. With the main priority of development and funding of basic needs they try to attract foreign investments, and as such they are the importers of capital. Among so called "developing countries" there is a group of territories which start to play a significant role on international arena as capital exporters - Brazil, Russia, India, China and South Africa (further: BRICS). BRICS is a group of large, fast growing territories, with dynamic labour forces and emerging consumer market, but yet having not much in common. Those countries do not speak with one voice; on the contrary, among them there are a lot of tensions and divergent interests. Regardless of the lack of consistency in their attitudes, the role of these countries in the world economy cannot be underestimated. Together the BRICS account for $26 \%$ of the world's landmass and $42 \%$ of the global population. While in the year 2000 the BRICS (along with Indonesia) contributed $18 \%$ of global GDP, and industrialised nations contributed about $65 \%$, at present the group is responsible for $40 \%$ of the word GDP (USD 18,486 trillion). The estimations show that within three years the BRICS' total GDP will be larger than that of the United States and in the next eight years will reach up to $50 \%$ of the global GDP - with China being billed to overtake the US economy by 2027 (BRICS Joint...,2012). All those estimates mean the great shift of those economic powers from traditional developed countries to emerging economies.

There is also a substantial change in the field of business entities active at the international arena. It is visible in the new type of multinational enterprises, having an origin in BRIC countries. BRIC-headquartered companies expand beyond their regions in search of new markets and resources and become true global companies with brand names, management skills and competitive business models. The change in 2011 Fortune Global 500 reflects the phenomenon - the last decade have brought the growth in BRIC origin companies from 16 to 77 (Neubig, Kinrade, Young, 2011). As the result of rapid economic growth in their home countries, MNEs from BRICS become important investors, abundant financial resources and strong motivations to acquire resources and strategic assets abroad. According to UNCTAD World Investment Report (2011) in 2010 there were seven mega-deals (over USD 3 billion) involving developing and transition economies $12 \%$ of the total), compared to only two (3\% of the total) in 2009.

Emerging economies, particularly Brazil, China, India and the Russia have gained ground as sources of FDI in recent years. Good business model, low cost, good logistic and the priority to the technology cause also the massive increase in the intra-regional trade, especially among the BRICS partners (USD 230 billion). Estimations show that by 2015 the five economies will aim to double intra-regional trade to USD 500 billion. It is the next reason which makes the emerging economies becoming less peripheral, and OECD countries slowly losing their central position.

Recent years have also brought some new challenges to analysed economies. One of them is an issue of domestic taxation, which suffers some constraints. The crisis affected the bigger and more developed economies with much greater extent than the smaller developing countries and was reflected in the decrease in the tax revenue ratio. Also the

economic indicators estimates for BRICS are not too optimistic for the nearest future, especially the GDP growth. Participants of the Fourth BRICS Summit in New Delhi 
(March 2012) stated that Chinese GDP growth forecast for 2012 is $7.5 \%$ as against the rate of $9.2 \%$ in 2011 . China is not the only economy losing the steam. Brazil's GDP is slowing down and the country's central bank has been slashing rates as a result. India's GDP grew at the lowest in the last three years during the fourth quarter of 2011 although it was relatively up at $6.1 \%$. South Africa has not addressed its energy problem yet and Russia is reeling under a heavy unemployment index (BRICS Joint..., 2012).

There are some other potential risk factors that can undermine the BRICS economies: the probability of political backlash (Brazil), the industrialisation and exchange rates as the risk for manufacturing industry (Brazil, Russia), the declining population as a future threat for cheap labour costs (Russia, China), huge social inequalities in emerging economies (India, China, Brazil), inflation, the risk of commodity prices, especially important for exporting countries (Brazil, Russia, South Africa), and also the risk of conflicts - both between regions (centralstate conflicts in Brazil and India), and block of countries having separable interests.

Among the goals important for the new players the most important seem to be: broadening the tax base and structuring the tax system in order to ensure tax revenues. There is also an issue of potential new sources of taxes. The bigger perspectives are seen in the growing middle class population and the development of new products (like developing services). The change in the status of BRICS countries - from capital importing to capital exporting territories has a wide impact not only on the tax system but also on investment incentives used on their territories and their treaty policy (old vs. new) and negotiating power. It happens more often that developing countries start to be those players, which have stronger position during tax treaties' negotiations. It allows them forcing solutions, consistent with their economic goals and tax policies.
The evolution of emerging economies and the change of their international role cause that their reality is becoming much complex. It creates possible problems arising from the change of their position. As the result of rapid economic growth in their home countries, MNEs from BRICS become important investors, abundant financial resources and strong motivations to acquire resources and strategic assets abroad. As a consequence those dynamically developing countries will need to look carefully at their international tax arrangements and to review their traditional point of view - with perceiving themselves as capital importing countries defending the right to source-taxation, as an opposition to capital exporting countries' putting an emphasis on resident-taxation.

\section{Conclusions}

The problem of multinational enterprises and their real influence on situation of developing countries was noticed by developed territories and international organisations. From their perspective there is a strong need of bringing developing countries to the net of double agreements, to stimulate dialogue and to help them in implementing reasonable systems of tax incentives. This opinion has remained unchanged for years. But the growing role of transnational corporations and the scale of "race to the bottom" caused the change in the voice of international organisations. According to J. Owens, Head of the OECD's Centre for Tax Policy Administration, nowadays very crucial in the process of attracting the foreign capital through tax incentives and the network of tax treaties is making sure that the developing countries will benefit from such instruments and moreover - that they will have capacity to manage them.

It must be also remembered that taxes are very political issue, so that will always be a threat of aggressive practices on the side with stronger position. Emerging territories need not only to identify what is important for their policy, but also to keep it in mind 
during the tax treaties' negotiations. That will help to create a tax system and the net of international tax agreements which would serve not only as a tool for attracting foreign direct investments, but as a consistent element of their tax and development policy.

In the new reality, with new players on international taxation arena, there is also a need of rethinking the role of international organisations, especially the United Nations. The UN ought to put more tension on developing countries and their real goals, with special emphasis on helping the emerging economies in working out one coherent position in tax treaties' negotiation process. There will be also a growing role of international fora, discussing the issues of international tax relations, treaties and tax administration (with OECD and BRICS as participants). For international organisations there is a need to remember about the necessity to take into account the aims and possibilities of smaller and less developed territories, as at present there is no real voice for developing countries in those international initiatives. Probably in the future there will be a new balance of powers on international arena: OECD vs. BRICS vs. the rest of the world. As a consequence, there will be a need for different levels of discussion: (1) negotiations BRICS-OECD, with the emphasis on the future perspective for international tax architecture, and (2) the developed-developing countries, with the discussion about their possible mutual relations.

\section{References}

"A World of Difference: Why Some Australians Keep Getting Richer," (2012). Knowledge@Australian School of Business (05.02.2012), [Online] [retrieved 13.05.2012],

http://knowledge.asb.unsw.edu.au/article.cf $\mathrm{m}$ ?articleid $=1535$

Brauner, Y. (2012). 'The Future of Tax Incentives in Developing Countries,' Conference From Tax Havens to International
Tax Coordination: A Focus on Non-OECD Countries \& Development, Florence, 25.05.2012.

"BRICS Joint Statistical Publication 2012," (2012). [Online] [retrieved 16.05.2012], http://www.bricsindia.in/publication.html

Brodzka, A. \& Garufi, S. (2012). "The Era of Exchange of Information and Fiscal Transparency: The Use of Soft Law Instruments and the Enhancement of Good Governance in Tax Matters," European Taxation Vol. 52, IBFD, 401-404.

Cooperating with Developing Countries on Promoting Good Governance in Tax Matters, (2010). Communication from the Commission to the Council, the European Parliament and the Economic and Social Committee, SEC(2010) 426, 21.04.2010.

Cottarelli, C. (2011). "Revenue Mobilization in Developing Countries," International Monetary Fund, 08.03.2011, 8-10.

Holland, D. \& Vann, R. J. (1998). "Income Tax Incentives for Investment," in: Thuronyi V. (ed.), Tax Law Design and Drafting, Volume 2, International Monetary Fund, 2-9.

Neubig, T., Kinrade, T. \& Young, T. (2011). "Landscape Changing for Headquarter Locations: An Update," Ernst \& Young Center for Tax Policy, 2.

Nielsen, L. (2011). "Classifications of Countries Based on Their Level of Development: How it is Done and How it Could be Done," IMF Working Paper, 3-5.

Owens, J. (2012). 'The Role of Tax in Promoting Development,' Conference From Tax Havens to International Tax Coordination: $A$ Focus on Non-OECD Countries \& Development, Florence, 2-5.05.2012.

"Political Economy of Taxation in Africa: Fiscal Legitimacy and Public Expenditure," OECD (2007). [Online] [retrieved 18.05.2012], 
9 Journal of Economics Studies and Research

http://www.oecd.org/site/devaeo10/44273 441.pdf

Ravallion, M. (2011). “A Comparative Perspective on Poverty Reduction in Brazil, China, and India," World Bank, 26(1), 2-7.

"Tax Havens and Development - Status, Analyses and Measures," (2009). Norwegian Government Commission Report, 64.

World Investment Report 2011, UNCTAD, $34 \mathrm{v}$. 